\title{
Electrophysiologic testing aids diagnosis and subtyping of myoclonus
}

Rodi Zutt, MD, Jan W. Elting, MD, PhD, Jonathan C. van Zijl, MD, J. Han van der Hoeven, MD, PhD, Christiaan M. Roosendaal, MD, Jeannette M. Gelauff, MD, Kathryn J. Peall, MD, PhD, and

Marina A.J. Tijssen, MD, PhD

Neurology ${ }^{\circledR}$ 2018;90:e647-e657. doi:10.1212/WNL.0000000000004996

\author{
Correspondence \\ Dr. Tijssen \\ m.a.j.de.koning-tijssen@ \\ umcg.nl
}

\begin{abstract}
\section{Objective}

To determine the contribution of electrophysiologic testing in the diagnosis and anatomical classification of myoclonus.

\section{Methods}

Participants with a clinical diagnosis of myoclonus were prospectively recruited, each undergoing a videotaped clinical examination and battery of electrophysiologic tests. The diagnosis of myoclonus and its subtype was reviewed after 6 months in the context of the electrophysiologic findings and specialist review of the videotaped clinical examination.
\end{abstract}

\section{Results}

Seventy-two patients with myoclonus were recruited. Initial clinical anatomical classification included 25 patients with cortical myoclonus, 7 with subcortical myoclonus, 2 with spinal myoclonus, and 15 with functional myoclonic jerks. In 23 cases, clinical anatomical classification was not possible because of the complexity of the movement disorder. Electrophysiologic testing was completed in 66, with agreement of myoclonus in 60 (91\%) and its subtype in 28 (47\%) cases. Subsequent clinical review by a movement disorder specialist agreed with the electrophysiologic findings in 52 of 60 ; in the remaining 8 , electrophysiologic testing was inconclusive.

\section{Conclusions}

Electrophysiologic testing is an important additional tool in the diagnosis and anatomical classification of myoclonus, also aiding in decision-making regarding therapeutic management. Further development of testing criteria is necessary to optimize its use in clinical practice. 


\section{Glossary}

CHAID = Chi-squared Automatic Interaction Detection; $\mathbf{C M}=$ cortical myoclonus; $\mathbf{C S}=$ cortical spike; FJ = functional jerks; GCI-S = Global Clinical Impression-Severity; ICC = intraclass correlation coefficient; MMS = multiple myoclonus subtype; PM = peripheral myoclonus; $\mathbf{S C M}$ = subcortical myoclonus; $\mathbf{S M}=$ spinal myoclonus; $\mathbf{S S E P}$ = somatosensory evoked potential; UMRS = Unified Myoclonus Rating Scale.

Myoclonus is a frequently observed hyperkinetic movement disorder, which is often classified according to its anatomical origin: cortical myoclonus (CM), subcortical myoclonus (SCM), spinal myoclonus (SM), peripheral myoclonus $(\mathrm{PM})$, or functional jerks (FJ) in case of a functional movement disorder.

Electrophysiologic testing is frequently useful in distinguishing myoclonus from other hyperkinetic movement disorders, and in identifying its anatomical origin. ${ }^{1-3}$ The tests used in the assessment of myoclonus include polymyography, EEG-EMG back-averaging, coherence analysis, and somatosensory evoked potential (SSEP). ${ }^{4-8}$ Table 1 summarizes the electrophysiologic criteria used in the diagnosis of myoclonus and its subtypes.

The sensitivity and specificity of electrophysiologic testing in patients with myoclonus are largely unknown, with the majority of work to date being limited by small cohorts, highly selected patient populations, or reliance on expert opinion to determine the diagnosis. ${ }^{9-11}$

Our recent retrospective analysis of 85 patients with myoclonus demonstrated the key clinical and electrophysiologic features in distinguishing myoclonus subtypes. ${ }^{12}$ In $74 \%$ of cases, the clinical diagnosis of myoclonus was confirmed with electrophysiologic testing, and electrophysiologic assessment of the myoclonus subtype aided diagnosis in $73 \%$ of cases. In this study, we sought to apply these principles to a prospectively recruited cohort of patients, evaluating the contribution of electrophysiologic testing in the diagnosis and management of myoclonus.

\section{Methods}

\section{Participants}

Participants with a clinical diagnosis of myoclonus were identified prospectively from inpatient and outpatient settings (July 2014 to June 2016). Exclusion criteria included ongoing inpatient care on the intensive care unit, language and/or literacy barriers, and age 6 years or younger. All participants were followed up for a minimum of 6 months, after which a final diagnosis was made.

\section{Initial clinical classification}

The initial clinical diagnosis of myoclonus and its anatomical subtype was provided by the participants' primary caring neurologist (adult or pediatric), with all participants undergoing a standardized and systematic assessment, including videotaped clinical examination.

\section{Electrophysiologic testing}

The standardized electrophysiologic protocol included an initial polymyography, with participants excluded at this stage if the myoclonus was too subtle to adequately perform the assessment. For those meeting electrophysiologic criteria for myoclonus, further investigations included EEG-EMG backaveraging (if $>25$ jerks) or coherence analysis (if jerk frequency was $>3 \mathrm{~Hz}$ ). Where possible, those with $\mathrm{CM}$ and $\mathrm{SCM}$ underwent testing for SSEPs (figure e-1, http://links.lww. $\mathrm{com} / \mathrm{WNL} / \mathrm{A} 164)$.

An experienced neurophysiologist (J.W.E. and J.H.v.d.H.) blinded to the original clinical diagnosis determined whether the findings were consistent with myoclonus, and the likely myoclonus subtype. Table 1 summarizes the electrophysiologic criteria used in determining diagnosis. ${ }^{12}$

\section{Diagnostic review and 6-month follow-up}

A neurologist with expertise in movement disorders (M.A.J.T.), blinded to the initial diagnoses, reviewed the clinical details, videotaped clinical examination, and results of the electrophysiologic testing. Each patient was reviewed again 6 months after their initial assessment to determine any changes to the clinical findings, with the final diagnosis being confirmed by the specialist (figure 1).

\section{Severity of the myoclonus}

The severity of the myoclonus was determined by 2 independent clinicians (R.Z. and J.C.v.Z. or J.M.G.) following review of the videotaped clinical examinations, scoring sections 2 and 4 of the Unified Myoclonus Rating Scale (UMRS), and the 7-point Global Clinical Impression-Severity (GCI-S) scale.

\section{Power analysis}

A power calculation was performed based on our previously reported retrospective analysis. ${ }^{12}$ It was estimated that electrophysiologic testing would support the clinical diagnosis of the myoclonus anatomical subtype in approximately $70 \%$. A change in clinical classification of $>20 \%$, due to electrophysiologic testing, was considered clinically relevant. Using the One Proportion Confidence Interval Formula: Exact (Clopper-Pearson), a 95\% confidence level, 0.7 (proportion), 0.8 (upper limit), we estimated that a minimum of 56 participants would need to be recruited.

\section{Statistical analysis}

The clinical characteristics were analyzed using KruskalWallis tests for continuous, nonnormally distributed data. 
Table 1 Electrophysiologic criteria of myoclonus and to aid diagnosis by anatomical subtype ${ }^{12}$

\begin{tabular}{|c|c|c|c|}
\hline Myoclonus/anatomical subtype & Video-polymyography & $\begin{array}{l}\text { Back-averaging/coherence } \\
\text { analysis/SSEP }\end{array}$ & $\begin{array}{l}\text { Importance of } \\
\text { criterion }\end{array}$ \\
\hline \multirow[t]{2}{*}{ Myoclonus } & $\begin{array}{l}\text { Abrupt muscle contraction or } \\
\text { interruption of muscle activity }\end{array}$ & & Required \\
\hline & $\begin{array}{l}\text { Synchronous contraction of agonist } \\
\text { and antagonist muscles }{ }^{8,19}\end{array}$ & & Supportive \\
\hline \multirow[t]{6}{*}{ Cortical myoclonus } & $\begin{array}{l}\text { Burst duration positive myoclonus } \\
<100 \mathrm{~ms}\end{array}$ & & Required \\
\hline & Multifocal/focal distribution & & Supportive \\
\hline & Presence of negative myoclonus ${ }^{8}$ & & Supportive \\
\hline & & $\begin{array}{l}\text { Positive cortical spike back-averaging: } \\
\text { Presence of a "time locked" biphasic } \\
\text { potential >2 SD above baseline on the } \\
\text { contralateral motor cortex preceding } \\
\text { the jerks seen on the EMG according } \\
\text { to the conduction time of } \\
\text { corticospinal pathways (arms } 15-25 \\
\mathrm{~ms} / \text { legs } \pm 40 \mathrm{~ms})^{8,20}\end{array}$ & Diagnostic \\
\hline & & $\begin{array}{l}\text { Positive corticomuscular coherence: } \\
\text { Occurrence of significant } \\
\text { corticomuscular coherence in the } \\
\text { alpha and beta band with a phase } \\
\text { difference consistent with a cortical } \\
\text { generator }^{6,7,21}\end{array}$ & Diagnostic \\
\hline & & $\begin{array}{l}\text { Presence of a giant SSEP: The P } 27 \text { and } \\
\text { N35 peaks had large amplitudes }>5 \\
\mu V \text { and had a suitable shape } e^{20,22,23}\end{array}$ & Diagnostic \\
\hline
\end{tabular}

\section{Subcortical myoclonus}

\begin{tabular}{|c|c|c|}
\hline Brainstem & Burst duration $>100 \mathrm{~ms}$ & Supportive \\
\hline & $\begin{array}{l}\text { Simultaneous rostral and caudal } \\
\text { muscle activation at brainstem } \\
\text { level }^{24,25}\end{array}$ & Required \\
\hline \multirow[t]{3}{*}{ M-D/other } & Burst duration $>100 \mathrm{~ms}$ & Supportive \\
\hline & Presence of negative myoclonus & Supportive \\
\hline & $\begin{array}{l}\text { Do not meet criteria of other } \\
\text { categories }^{26}\end{array}$ & Required \\
\hline \multicolumn{3}{|l|}{ Spinal myoclonus } \\
\hline \multirow[t]{3}{*}{ Segmental } & Burst duration $>100 \mathrm{~ms}$ & Supportive \\
\hline & $\begin{array}{l}\text { Distribution according to } 1 \text { or } 2 \\
\text { contiguous spinal segments }\end{array}$ & Required \\
\hline & Rhythmic (1-2/min to $240 / \mathrm{min})$ & Supportive \\
\hline \multirow[t]{3}{*}{ Propriospinal } & Burst duration $>100 \mathrm{~ms}^{20}$ & \\
\hline & $\begin{array}{l}\text { Initiation in mid thoracic segments } \\
\text { followed by rostral and caudal } \\
\text { activation } 27,28\end{array}$ & Required \\
\hline & $\begin{array}{l}\text { Propagation with slow velocity (5-15 } \\
\mathrm{m} / \mathrm{s}) \text { in } \text { cord }^{20}\end{array}$ & Required \\
\hline \multirow[t]{4}{*}{ Peripheral myoclonus } & Burst duration $<50 \mathrm{~ms}$ & Required \\
\hline & Large MUAPs & Supportive \\
\hline & $\begin{array}{l}\text { Minipolymyoclonus or fasciculations/ } \\
\text { myokymia }\end{array}$ & Supportive \\
\hline & Accompanied by weakness/atrophy ${ }^{29}$ & Supportive \\
\hline
\end{tabular}


Table 1 Electrophysiologic criteria of myoclonus and to aid diagnosis by anatomical subtype ${ }^{12}$ (continued)

\begin{tabular}{|c|c|c|c|}
\hline Myoclonus/anatomical subtype & Video-polymyography & $\begin{array}{l}\text { Back-averaging/coherence } \\
\text { analysis/SSEP }\end{array}$ & $\begin{array}{l}\text { Importance of } \\
\text { criterion }\end{array}$ \\
\hline \multirow[t]{4}{*}{ Functional jerks } & Variable muscle recruitment & & Supportive \\
\hline & Variable burst duration (>100 ms) & & Supportive \\
\hline & Distractibility and/or entrainment ${ }^{1,30}$ & & Supportive \\
\hline & & $\begin{array}{l}\text { Presence of a Bereitschaftspotential: } \\
\text { Presence of a clear slow negative } \\
\text { electrical shift }(>5 \mu \mathrm{V}) \text { over the central } \\
\text { cortical areas that increased over } \\
\text { time } 1-2 \text { s before movement onset }{ }^{5,31}\end{array}$ & Diagnostic \\
\hline
\end{tabular}

Abbreviations: M-D = myoclonus dystonia; MUAP = motor unit action potential; SSEP = somatosensory evoked potential.

Interrater reliability was assessed using the intraclass correlation coefficient (ICC) (2-way mixed, consistency, average measures $){ }^{13}$ or Cohen $\kappa^{14}$ where appropriate. A Chi-squared Automatic Interaction Detection (CHAID) (SPSS, IBM, Armonk, NY; parent nodes $\mathrm{n}<3$, child nodes $\mathrm{n}>1$ ) analysis was undertaken to generate a decision tree in order to quantify the importance of the clinical and electrophysiologic criteria in the diagnosis of the myoclonic subtypes.

\section{Standard protocol approvals, registrations, and patient consents}

Full written informed consent was obtained from all participants according to the Declaration of Helsinki. The study protocol was approved by the University Medical Centre Groningen ethics committee (M14.157933, approved July 2, 2014).

\section{Results}

\section{Overall cohort}

A total of 72 patients ( 32 male; 40 female) were recruited, with a median age of 29 years (range: $7-83$ years), 59 from the outpatient setting and 13 from inpatient care.

The demographic details and clinical characteristics of this cohort are summarized in table 2 and table e-1 (http://links. lww.com/WNL/A165), respectively.

Figure 1 Overview of the stages of clinical assessment and diagnosis undertaken in this study

\begin{tabular}{|c|c|c|c|c|c|}
\hline \multicolumn{2}{|c|}{$\begin{array}{c}\text { Step 1: } \\
\text { Initial clinical diagnosis }\end{array}$} & \multicolumn{2}{|c|}{$\begin{array}{l}\text { Step 2: } \\
\text { Electrophysiologic testing vs initial diagnosis }\end{array}$} & \multicolumn{2}{|c|}{$\begin{array}{c}\text { Step 3: } \\
\begin{array}{c}\text { Expert opinion after electrophysiologic testing }= \\
\text { final diagnosis }\end{array}\end{array}$} \\
\hline Myoclonus & \multirow{6}{*}{$\begin{array}{l}\text { Myoclonus subtype } \\
\begin{array}{|l}\cdot \text { CM }(n=25) \\
\cdot \text { SCM }(n=7) \\
\cdot \text { SM }(n=2) \\
\cdot \text { FJ }(n=15) \\
\cdot \text { Not classified }(n=23)\end{array}\end{array}$} & Myoclonus yes/no & Myoclonus subtype & Myoclonus yes/no & Myoclonus subtype \\
\hline \multirow[t]{5}{*}{$\begin{array}{l}\text { Diagnosed with } \\
\text { myoclonus } \\
(\mathrm{N}=72) \\
\end{array}$} & & $\begin{array}{l}\text { Too subtle for testing } \\
(n=6,8 \%)\end{array}$ & & & \\
\hline & & $\begin{array}{l}\text { Agreement myoclonus } \\
\qquad(\mathrm{n}=60,91 \%)\end{array}$ & $\begin{array}{l}\text { Agreement } \\
\text { subtype }\end{array}$ & Agreement & $\begin{array}{l}\text { Agreement subtype } \\
\qquad(n=52,87 \%)\end{array}$ \\
\hline & & \begin{tabular}{l}
\multicolumn{1}{c}{ No myoclonus } \\
$\qquad(n=6,9 \%)$ \\
New diagnoses $(n=6)$ : \\
- Tremor (3) \\
- Chorea (1)
\end{tabular} & $\begin{array}{c}\begin{array}{c}\text { First classification } \\
(n=17,28 \%)\end{array} \\
\end{array}$ & $\begin{array}{l}\text { Agreement } \\
\text { alternative } \\
\text { diagnoses } \\
(n=4,100 \%)\end{array}$ & $\begin{array}{l}\text { No agreement subtype } \\
(n=8,13 \%): \\
\cdot \text { CM (4) } \\
\cdot \text { SCM (1) } \\
\cdot \text { FJ (3) }\end{array}$ \\
\hline & & - MD undetermined (2) & $\begin{array}{l}\text { No agreement } \\
\text { subtype } \\
(n=15,25 \%)\end{array}$ & $\begin{array}{c}\text { Agreement MD } \\
\text { undetermined } \\
(\mathrm{n}=2,100 \%)\end{array}$ & \\
\hline & & & $\begin{array}{l}\text { Electrophysiologic } \\
\text { diagnoses }(n=60) \text { : } \\
\text { - CM (30) } \\
\cdot \text { SCM (10) } \\
\text { - MMS (3) } \\
\text { - FJ (17) }\end{array}$ & & $\begin{array}{l}\text { Final diagnoses }(n=60) \text { : } \\
\cdot \operatorname{CM}(33) \\
\cdot \operatorname{SCM}(4) \\
\cdot \operatorname{MMS}(3) \\
\cdot \operatorname{FJ}(20)\end{array}$ \\
\hline
\end{tabular}

$\mathrm{CM}=$ cortical myoclonus; $\mathrm{FJ}$ = functional jerks; $\mathrm{MD}=$ movement disorder; $\mathrm{MMS}=$ multiple myoclonus subtypes; $\mathrm{SCM}=$ subcortical myoclonus; $\mathrm{SM}=$ spinal myoclonus. 
Table 2 Demographic features of the myoclonus cohort

\begin{tabular}{|c|c|c|c|c|c|}
\hline Demographic features & CM $(n=33)$ & $\operatorname{SCM}(n=4)$ & $\mathrm{FJ}(\mathrm{n}=20)$ & MMS (n = 3) & Total $(n=60)$ \\
\hline Sex, M/F & $15 / 18$ & $2 / 2$ & $7 / 13$ & $1 / 2$ & $25 / 35$ \\
\hline Age at examination, $y^{a}$ & $21(7-83)$ & $18.5(15-48)$ & $31.5(16-73)$ & $63(18-73)$ & $22(7-83)$ \\
\hline Age at onset of myoclonus, $y^{a}$ & $14(0-83)$ & $11(10-14)$ & $25(12-66)$ & $60(4-73)$ & $18(0-83)$ \\
\hline Follow-up interval, mo ${ }^{b}$ & 21 & 22 & 22 & 15 & 20 \\
\hline \multicolumn{6}{|l|}{ UMRS $^{\mathrm{a}}$} \\
\hline Rest & $9(0-38)$ & $14(9-23)$ & $17(2-30)$ & $9(6-18)$ & $11(0-38)$ \\
\hline Action & $19(6-57)$ & $15(7-23)$ & $8(0-33)$ & $16(0-31)$ & $15(0-57)$ \\
\hline Total & $31(7-85)$ & $31(19-42)$ & $23(5-62)$ & $28(6-49)$ & $27(5-85)$ \\
\hline GCI-S ${ }^{a}$ & $3(2-7)$ & $4(3-5)$ & $4(2-6)$ & $4(3-5)$ & $4(2-7)$ \\
\hline Family history of a related disorder & 7 & 3 & 2 & 1 & 13 \\
\hline \multicolumn{6}{|l|}{ Other neurologic symptoms } \\
\hline Eye movement disorder & 8 & 0 & 0 & 0 & 8 \\
\hline Dystonia & 9 & 4 & 0 & 1 & 14 \\
\hline Chorea & 3 & 0 & 0 & 0 & 3 \\
\hline Ataxia & 4 & 0 & 0 & 0 & 4 \\
\hline \multicolumn{6}{|l|}{ Comorbidity } \\
\hline Psychiatric & 5 & 0 & 4 & 0 & 9 \\
\hline Epilepsy & 9 & 0 & 0 & 0 & 9 \\
\hline Cognitive problems & 7 & 2 & 0 & 0 & 9 \\
\hline Liver or kidney disease & 5 & 0 & 2 & 0 & 7 \\
\hline Structural damage to brain & 3 & 0 & 1 & 0 & 4 \\
\hline \multicolumn{6}{|l|}{ Treatment } \\
\hline No treatment & 14 & 3 & 5 & 1 & 23 \\
\hline Clonazepam & $9(4)$ & 0 & 0 & $2(2)$ & $11(6)$ \\
\hline Levetiracetam & $9(6)$ & 0 & 0 & 0 & $9(6)$ \\
\hline Valproic acid & $3(1)$ & $1(0)$ & 0 & $1(0)$ & $5(1)$ \\
\hline Multiple drug therapy & $5(4)$ & 0 & 0 & 0 & $5(4)$ \\
\hline Physiotherapy & 0 & 0 & $10(5)$ & $1(1)$ & $11(6)$ \\
\hline Explanation diagnosis & $0(0)$ & $0(0)$ & $5(5)$ & $0(0)$ & $5(5)$ \\
\hline \multicolumn{6}{|l|}{ Side effects, yes/no } \\
\hline Clonazepam & $5 / 4$ & $0 / 0$ & $0 / 0$ & $0 / 2$ & $5 / 6$ \\
\hline Levetiracetam & $7 / 2$ & $0 / 0$ & $0 / 0$ & $0 / 0$ & $7 / 2$ \\
\hline Valproic acid & $3 / 0$ & $0 / 1$ & $0 / 0$ & $0 / 1$ & $3 / 2$ \\
\hline Multiple drug therapy & $3 / 2$ & $0 / 0$ & $0 / 0$ & $0 / 0$ & $3 / 2$ \\
\hline
\end{tabular}

Abbreviations: $\mathrm{CM}$ = cortical myoclonus; FJ = functional jerks; GCI-S = Global Clinical Impression-Severity; MMS = multiple myoclonus subtypes; SCM = subcortical myoclonus; UMRS = Unified Myoclonus Rating Scale.

Classification of myoclonus is given as the final diagnosis following review at 6 months post diagnosis. Treatment: the number in parentheses is the number of patients in whom the myoclonus improved with treatment.

a values are displayed as median (range).

${ }^{b}$ Values are displayed as mean. 


\section{Clinical diagnosis of myoclonus pre- electrophysiologic testing}

Of the 72 individuals with myoclonus, these were subdivided into CM $(n=25), \operatorname{SCM}(n=7), \operatorname{SM}(n=2)$, and FJ $(n=15)$, with subtype diagnoses not possible in 23 patients (32\%) because of the complexity of the movement disorder.

\section{Electrophysiologic diagnoses}

In 6 patients (8\%), clinically diagnosed with distal multifocal $\mathrm{CM}$, the myoclonic jerks were of such small amplitude that the polymyographic recordings were indeterminate and unable to be interpreted. Of the remaining 66 patients, electrophysiologic testing supported a diagnosis of myoclonus in $60(91 \%)$, with these subdivided into CM $(\mathrm{n}=30)$, SCM $(\mathrm{n}=10)$, multiple myoclonus subtypes (MMS) $(\mathrm{n}=3)$, and FJ $(\mathrm{n}=17)$. A cortical origin was detected in 5 of 9 patients (60\%) with CM using back-averaging, and 16 of $20(80 \%)$ using coherence analysis. SSEP analysis demonstrated giant potentials in 3 of 14 patients (21\%) with $\mathrm{CM}$, and a Bereitschaftspotential was identified in 5 of 12 patients (42\%) with FJ.

A full summary of the electrophysiologic characteristics of this cohort can be seen in table 3 .

\section{Comparison of clinical and electrophysiologic diagnoses}

There was agreement between the clinical diagnosis and electrophysiologic testing in a diagnosis of myoclonus for $91 \%$ $(60 / 66)$ of the study cohort. Of these 60 cases, there was agreement of its subtype in 28 cases (47\%) (14 CM, 2 SCM, and $12 \mathrm{FJ})$ and disagreement in 15 cases $(25 \%)$. Of the remaining 17 cases $(28 \%)$ without a clinical subclassification, electrophysiologic testing proved helpful, subdividing these into $12 \mathrm{CM}, 2 \mathrm{SCM}$, and $3 \mathrm{FJ}$ (table e-2, http://links.lww. com/WNL/A165).

\section{Clinical opinion of the movement disorder specialist}

There was agreement between the electrophysiologic testing and specialist movement disorder opinion in 66 cases, and agreement on its subtype in 52 of 60 cases (87\%), considered a "substantial" agreement $(\kappa=0.78)$. A summary of the 8 cases in which there was disagreement between expert clinical diagnosis and electrophysiologic testing is provided in table 4; in each, there was a lack of conclusive electrophysiologic findings to facilitate a diagnosis of myoclonus subtype.

\section{Final clinical diagnoses}

Follow-up review after 6 months resulted in no changes to clinical diagnosis in all 60 patients, with the final subclassification including $33 \mathrm{CM}$ (55\%), 4 SCM (7\%), 3 MMS (5\%), and $20 \mathrm{FJ}$ (33\%). The CHAID analysis demonstrated (1) polymyographic measurement of the myoclonic burst duration, (2) exacerbation of the myoclonus with action, and (3) facial involvement to be the most important criteria in determining myoclonic subtype (figure e-2, http://links.lww. com/WNL/A164).

\section{Severity of myoclonus}

The median UMRS severity score was 27 (Rest 11/128, Action 15/144) and GCI-S score 4/7. No significant statistical difference was observed between the subtypes of myoclonus $(p=0.2)$. The interrater concordance was "excellent" (ICC = 0.94 [95\% confidence interval: 0.9-0.96]) and "good" (ICC = 0.72 [95\% confidence interval: $0.58-0.82]$ ) for the UMRS and GCI-S, respectively.

\section{Underlying etiology of the myoclonus}

Of the 40 patients diagnosed with an organic movement disorder, an underlying etiology was identified in 21 patients (53\%). In 12 patients, a causative genetic mutation was identified, and 9 were found to have an acquired cause including metabolic disturbances $(\mathrm{n}=3)$, drug-induced myoclonus $(\mathrm{n}=1)$, and structural brain lesions $(\mathrm{n}=2)$. Of those with an underlying genetic etiology, the highest rate was among those with CM $(\mathrm{n}=10)$, with mutations in the NKX2.1 $(\mathrm{n}=2)$ and NPC1 $(\mathrm{n}=2)$ genes being most common. A single case of a contiguous gene deletion $(578 \mathrm{~kb}$, 16p11.2) involving the PRRT2 gene was identified with an extended phenotype including psychomotor retardation, hemiplegic migraine, epilepsy, myoclonus, and dystonia. All patients with a myoclonic epilepsy syndrome had evidence of epileptiform discharges on EEG, with the CM in those with juvenile myoclonic epilepsy and Lafora disease demonstrating an epileptic origin. All 4 patients with SCM had a clinical diagnosis of myoclonus dystonia, with a RELN variant identified in one patient. Table 5 summarizes the etiologic diagnoses and additional clinical characteristics.

\section{Discussion}

This prospective study has sought to demonstrate the benefit of electrophysiologic testing alongside clinical examination, in determining the diagnosis of myoclonus and its subtype in an unselected cohort. We have shown that this combined approach leads to changes in the initial diagnosis of myoclonus and its subtype in $53 \%$ of cases.

Overall, agreement of a diagnosis of myoclonus between the examining clinicians and the electrophysiologic findings was $91 \%(\mathrm{n}=60)$, decreasing to $47 \%(\mathrm{n}=28)$ with anatomical subtype. These findings contrast with results from similar studies in tremor cohorts $(\mathrm{n}=210)$ where agreement between the 2 assessment forms was $87 \%$, potentially reflecting greater clinical familiarity and larger patient cohorts. ${ }^{15-17}$ We identified several clinical groups in which there was some consistency in the change in diagnosis following electrophysiologic testing. These included those with multifocal myoclonus (principally distinguishing between $\mathrm{CM}$ and SCM), combined movement disorders (e.g., myoclonus in the presence of dystonia), and functional jerks. The findings from this study also reflect the difficulty in determining a conclusive clinical diagnosis with myoclonus, and lend weight to the importance of electrophysiologic testing, particularly in nonspecialist centers. 
Table 3 Electrophysiologic characteristics of each subtype based on the electrophysiologic findings

\begin{tabular}{|c|c|c|c|c|c|}
\hline Electrophysiologic characteristics & $\mathrm{CM}$ & SCM & FJ & MMS & Total \\
\hline No. & 30 & 10 & 17 & 3 & 60 \\
\hline \multicolumn{6}{|l|}{ Type } \\
\hline Positive & 15 & 8 & 17 & 2 & 42 \\
\hline Negative & 0 & 1 & 0 & 0 & 1 \\
\hline Both & 15 & 1 & 0 & 1 & 17 \\
\hline \multicolumn{6}{|l|}{ Burst duration, ms } \\
\hline $30-50$ & 2 & 0 & 0 & 1 & 3 \\
\hline $50-100$ & 27 & 2 & 0 & 1 & 30 \\
\hline $50-200$ & 0 & 5 & 1 & 1 & 7 \\
\hline $100-300$ & 0 & 1 & 3 & 0 & 4 \\
\hline$>300$ & 0 & 0 & 2 & 0 & 2 \\
\hline Variable & 1 & 2 & 11 & 0 & 14 \\
\hline \multicolumn{6}{|l|}{ Distribution } \\
\hline Focal & 1 & 1 & 0 & 1 & 3 \\
\hline Multifocal & 29 & 9 & 7 & 1 & 46 \\
\hline Segmental & 0 & 0 & 0 & 1 & 1 \\
\hline Generalized & 0 & 0 & 0 & 0 & 0 \\
\hline Variable & 0 & 0 & 10 & 0 & 10 \\
\hline \multicolumn{6}{|l|}{ Back-averaging } \\
\hline CS present & 5 & 0 & 0 & 2 & 7 \\
\hline BP present & 0 & 0 & 5 & 0 & 5 \\
\hline CS absent & 4 & 3 & 0 & 0 & 7 \\
\hline BP absent & 0 & 1 & 7 & 0 & 8 \\
\hline Not performed & 15 & 1 & 0 & 1 & 17 \\
\hline Not possible & 6 & 5 & 5 & 0 & 16 \\
\hline \multicolumn{6}{|l|}{ Positive coherence } \\
\hline Present (segment sec) & 16 & 0 & 0 & 0 & 16 \\
\hline Absent (segment sec) & 4 & 4 & 0 & 1 & 9 \\
\hline Not performed & 10 & 6 & 17 & 2 & 35 \\
\hline \multicolumn{6}{|l|}{ Giant SSEP } \\
\hline Present & 3 & 0 & 0 & 0 & 3 \\
\hline Absent & 11 & 5 & 1 & 2 & 19 \\
\hline Not performed & 13 & 5 & 15 & 1 & 34 \\
\hline Unable to interpret & 3 & 0 & 1 & 0 & 4 \\
\hline
\end{tabular}

Abbreviations: $\mathrm{BP}=$ Bereitschaftspotential; $\mathrm{CM}$ = cortical myoclonus; $\mathrm{CS}=$ cortical spike; $\mathrm{F}$ = functional jerks; $\mathrm{MMS}=$ multiple myoclonus subtype; $\mathrm{SCM}=$ subcortical myoclonus; SSEP = somatosensory evoked potential.

Higher-level electrophysiologic techniques were used to determine whether the myoclonus was of cortical origin or an FJ. The yield of back-averaging and coherence analysis to confirm a cortical origin was $60 \%$ and $80 \%$, respectively. The additive value of these techniques was lower than the $100 \%$ seen in previous studies, potentially attributable to the heterogeneity 
Table 4 Details of cases in which the clinical diagnosis changed after evaluation by the movement disorders specialist

\begin{tabular}{|c|c|c|c|c|c|c|c|c|}
\hline No. & $\begin{array}{l}\text { Age at } \\
\text { onset, } y^{a}\end{array}$ & $\begin{array}{l}\text { Age at } \\
\text { examination, } y^{a}\end{array}$ & Clinical features & $\begin{array}{l}\text { Electrophysiologic } \\
\text { findings }\end{array}$ & $\begin{array}{l}\text { Electrophysiologic } \\
\text { diagnosis }\end{array}$ & $\begin{array}{l}\text { Expert clinical } \\
\text { diagnosis }\end{array}$ & $\begin{array}{l}\text { Final clinical } \\
\text { diagnosis }\end{array}$ & $\begin{array}{l}\text { Reasons for revising the } \\
\text { electrophysiologic diagnosis }\end{array}$ \\
\hline \multirow[t]{4}{*}{1} & 10 & 20 & Distal limbs and face & $50-200 \mathrm{~ms}$ & SCM & $\mathrm{CM}$ & CM & Distal distribution \\
\hline & & & Provocation by action & Back-averaging NP & & & & Facial involvement \\
\hline & & & Stimulus sensitive & & & & & Stimulus sensitivity \\
\hline & & & & & & & & No firm electrophysiologic results \\
\hline \multirow[t]{4}{*}{2} & 0 & 10 & Distal > proximal limbs & Positive and negative & SCM & $\mathrm{CM}$ & $\mathrm{CM}$ & Distal distribution \\
\hline & & & Face & $50-100 \mathrm{~ms}$ & & & & Facial involvement \\
\hline & & & Provocation by action & Back-averaging NP & & & & Stimulus sensitivity \\
\hline & & & Stimulus sensitive & & & & & No firm electrophysiologic results \\
\hline \multirow[t]{4}{*}{3} & 69 & 69 & Negative myoclonus & Negative & SCM & $\mathrm{CM}$ & $\mathrm{CM}$ & Negative myoclonus \\
\hline & & & Distal limbs & $50-100 \mathrm{~ms}$ & & & & Metabolic derangements \\
\hline & & & Provocation by action & Back-averaging NP & & & & No firm electrophysiologic results \\
\hline & & & $\begin{array}{l}\text { Metabolic } \\
\text { derangements }\end{array}$ & & & & & \\
\hline \multirow[t]{4}{*}{4} & 6 & 7 & Distal limbs & $50-200 \mathrm{~ms}$ & SCM & $\mathrm{CM}$ & $\mathrm{CM}$ & Distal distribution \\
\hline & & & Provocation by action & $\begin{array}{l}\text { Negative back- } \\
\text { averaging }\end{array}$ & & & & Stimulus sensitivity \\
\hline & & & Stimulus sensitive & & & & & Co-occurrence of epilepsy \\
\hline & & & Epilepsy & & & & & No firm electrophysiologic results \\
\hline \multirow[t]{4}{*}{5} & 16 & 17 & Acute onset & $50-200 \mathrm{~ms}$ & SCM & FJ & FJ & Acute onset \\
\hline & & & Distal upper limbs & $\begin{array}{l}\text { Negative back- } \\
\text { averaging }\end{array}$ & & & & Atypical sensory problems \\
\hline & & & Entrainment & & & & & Entrainment \\
\hline & & & $\begin{array}{l}\text { Atypical sensory } \\
\text { problems }\end{array}$ & & & & & No firm electrophysiologic results \\
\hline \multirow[t]{2}{*}{6} & 18 & 18 & Acute onset & Variable duration & $\mathrm{SCM}$ & FJ & FJ & Acute onset \\
\hline & & & Distal limbs & Multifocal & & & & Stimulus sensitive \\
\hline
\end{tabular}




\begin{tabular}{|c|c|c|c|c|c|c|c|c|}
\hline No. & $\begin{array}{l}\text { Age at } \\
\text { onset, } y^{a}\end{array}$ & $\begin{array}{l}\text { Age at } \\
\text { examination, } y^{a}\end{array}$ & Clinical features & $\begin{array}{l}\text { Electrophysiologic } \\
\text { findings }\end{array}$ & $\begin{array}{l}\text { Electrophysiologic } \\
\text { diagnosis }\end{array}$ & $\begin{array}{l}\text { Expert clinical } \\
\text { diagnosis }\end{array}$ & $\begin{array}{l}\text { Final clinical } \\
\text { diagnosis }\end{array}$ & $\begin{array}{l}\text { Reasons for revising the } \\
\text { electrophysiologic diagnosis }\end{array}$ \\
\hline & & & Stimulus sensitive & Back-averaging NP & & & & Change with distraction \\
\hline & & & $\begin{array}{l}\text { Change with } \\
\text { distraction }\end{array}$ & & & & & No firm electrophysiologic results \\
\hline \multirow[t]{5}{*}{7} & 20 & 20 & Subacute onset & $50-200 \mathrm{~ms}$ & SCM & FJ & FJ & Provocation by rest \\
\hline & & & Proximal and distal & $\begin{array}{l}\text { Negative back- } \\
\text { averaging }\end{array}$ & & & & Stimulus sensitive \\
\hline & & & Provocation by rest & & & & & Change with distraction \\
\hline & & & Stimulus sensitive & & & & & No firm electrophysiologic results \\
\hline & & & $\begin{array}{l}\text { Change with } \\
\text { distraction }\end{array}$ & & & & & \\
\hline \multirow[t]{3}{*}{8} & 14 & 20 & $\begin{array}{l}\text { Myoclonus, dystonia, } \\
\text { tremor }\end{array}$ & Positive and negative & $\mathrm{CM}$ & SCM & SCM & Combined myoclonus and dystonia \\
\hline & & & Cognitive difficulties & $50-100 \mathrm{~ms}$ & & & & No firm electrophysiologic results \\
\hline & & & Proximal and distal & Back-averaging NP & & & & \\
\hline
\end{tabular}

Abbreviations: $\mathrm{CM}$ = cortical myoclonus; $\mathrm{F}$ = functional jerks; NP = not performed; SCM = subcortical myoclonus.

a Values are displayed as median. 
Table 5 Underlying etiologic diagnoses and additional clinical characteristics

\begin{tabular}{|c|c|c|c|}
\hline $\begin{array}{l}\text { Myoclonus } \\
\text { subtype }\end{array}$ & Etiologic diagnosis or syndrome & Additional clinical characteristics & No. \\
\hline \multirow[t]{16}{*}{ CM $(n=33)$} & Juvenile Huntington (CAG repeat in HTT gene) & Cognitive impairment, severe epilepsy, spasticity & 1 \\
\hline & Wilson disease (mutation ATP7B gene) & Parkinsonism, dystonia, ataxia, cognitive impairment & 1 \\
\hline & Niemann-Pick type C (NPC1 mutation) & Eye movement disorder, ataxia, dystonia $(n=1)$ & 2 \\
\hline & Lafora disease (mutation NHLRC1 gene) & Severe epilepsy, mild cognitive impairment & 1 \\
\hline & Juvenile myoclonus epilepsy (no genetic mutation identified) & Epilepsy & 1 \\
\hline & Myoclonus epilepsy (no genetic mutation identified) & Epilepsy, mild cognitive impairment & 1 \\
\hline & Ramsay Hunt syndrome (GOSR mutation) & Ataxia, areflexia, eye movement disorder & 1 \\
\hline & Ramsay Hunt syndrome (no genetic mutation identified) & Ataxia, areflexia, eye movement disorder & 1 \\
\hline & Benign hereditary chorea (mutation NKX2.1 gene) & Chorea, dystonia, areflexia & 2 \\
\hline & $\begin{array}{l}\text { Paroxysmal kinesigenic dyskinesia (16p11.2 deletion [578 kb], } \\
\text { including the PRRT2 gene) }\end{array}$ & $\begin{array}{l}\text { Severe cognitive impairment, hemiplegic migraine, } \\
\text { epilepsy, dystonia }\end{array}$ & 1 \\
\hline & Myoclonus dystonia (18p11.21 deletion [14.9 Mb]) & Dystonia & 1 \\
\hline & Myoclonus dystonia (no genetic mutation identified) & $\begin{array}{l}\text { Dystonia, bradykinesia }(n=1) \text {, eye movement disorder } \\
(n=1)\end{array}$ & 2 \\
\hline & Medication-induced & Cognitive impairment $(n=1)$ & 2 \\
\hline & Metabolic derangements due to liver or kidney disease & Cognitive impairment $(n=2)$, polyneuropathy $(n=1)$ & 3 \\
\hline & Structural cerebral lesion & $\begin{array}{l}\text { Mild cognitive impairment }(n=1) \text {, vascular } \\
\text { parkinsonism }(n=1)\end{array}$ & 2 \\
\hline & Unknown & & 11 \\
\hline \multirow[t]{3}{*}{$\operatorname{SCM}(n=4)$} & Myoclonus dystonia (RELN variant) & Dystonia & 1 \\
\hline & Myoclonus dystonia (no genetic mutation identified) & Dystonia & 3 \\
\hline & Unknown & & 0 \\
\hline \multirow[t]{4}{*}{ MMS $(n=3)$} & Myoclonus dystonia (RELN variant) & Dystonia & 1 \\
\hline & Creutzfeldt-Jakob disease & Cognitive impairment, stiffness & 1 \\
\hline & Lumbar radiculopathy and FJ & Functional gait problem & 1 \\
\hline & Unknown & & 0 \\
\hline
\end{tabular}

Abbreviations: $\mathrm{CM}$ = cortical myoclonus; FJ = functional jerks; MMS = multiple myoclonus subtypes; SCM = subcortical myoclonus.

of our cohort in contrast to smaller, more selected study groups $(\mathrm{n}=20 / \mathrm{n}=3){ }^{9,18}$ A CHAID analysis demonstrated that a combination of polymyography (burst duration) and clinical phenomenology provided the greatest accuracy (95\%) in determining myoclonus subtype.

This study is limited by the lack of a definitive diagnostic test or marker. We have sought to reduce this by ensuring a minimum 6-month follow-up period to allow for any changes in clinical symptomatology. However, this lack of objective testing also serves to reinforce the potential gain of routine electrophysiologic testing to both aid, and provide additional evidence of the diagnosis of myoclonus and its subtype. Our cohort also likely reflects a more complex group of patients than might be expected in routine clinical practice, because of recruitment from a single specialist movement disorder center. We also acknowledge that while the electrophysiologic tests discussed are readily available within our center, such access varies considerably between centers and internationally.

Electrophysiologic testing is an important contributing diagnostic tool for the classification of myoclonus and its subtypes. While this clearly constitutes an important element of clinical work for neurologists with an interest in movement disorders, this algorithm of testing is also likely to be of use for those working in the fields of metabolic disorders, pediatrics, and epilepsy. Further development of the electrophysiologic criteria for myoclonus subtypes, and application of this work to larger, unselected patient cohorts is essential to improve its objectivity and diagnostic value. 


\section{Author contributions}

R. Zutt: design of the study, collecting data, analysis and interpretation of the data, drafting and revising the manuscript. J.W. Elting: design of the study, collecting data, revising the manuscript. J.C. van Zijl: collecting data, revising the manuscript. J.H. van der Hoeven, C.M. Roosendaal, and J.M. Gelauff: collecting data, revising the manuscript. K.J. Peall: analysis and interpretation of the data, drafting and revising the manuscript. M.A.J. Tijssen: design of the study, collecting data, analysis and interpretation of the data, drafting and revising the manuscript.

\section{Study funding}

No targeted funding reported.

\section{Disclosure}

R. Zutt and J.W. Elting report no disclosures relevant to the manuscript. J.C. van $\mathrm{Zijl}$ is funded by the $\mathrm{MD} / \mathrm{PhD}$ scholarship of the University of Groningen. J.H. van der Hoeven and C.M. Roosendaal report no disclosures relevant to the manuscript. J.M. Gelauff is funded by a scholarship from the Research School of Behavioural and Cognitive Neurosciences $(\mathrm{BCN})$, part of the University of Groningen. K.J. Peall is funded by an MRC Clinician-Scientist Fellowship (MR/ P008593/1). M.A.J. Tijssen is funded by STW Technology Society-NeuroSIPE, Netherlands Organization for Scientific Research-NWO Medium, Fonds NutsOhra, Prinses Beatrix Fonds, Gossweiler Foundation, Phelps Stichting, Stichting wetenschapsfonds dystonie vereniging, and educational grants from Ipsen, Allergan, Merz, Actelion, and Medtronic. Go to Neurology.org/ $\mathrm{N}$ for full disclosures.

Received June 23, 2017. Accepted in final form November 20, 2017.

\section{References}

1. van der Salm SM, de Haan RJ, Cath DC, van Rootselaar AF, Tijssen MA. The eye of the beholder: inter-rater agreement among experts on psychogenic jerky movement disorders. J Neurol Neurosurg Psychiatry 2013;7:742-747.

2. Erro R, Bhatia KP, Edwards MJ, Farmer SF, Cordivari C. Clinical diagnosis of propriospinal myoclonus is unreliable: an electrophysiologic study. Mov Disord 2013;28: 1868-1873.

3. Esposito M, Edwards MJ, Bhatia KP, Brown P, Cordivari C. Idiopathic spinal myoclonus: a clinical and neurophysiological assessment of a movement disorder of uncertain origin. Mov Disord 2009;24:2344-2349.

4. Shibasaki H, Nakamura M, Nishida S, Kakigi R, Ikeda A. Wave form decomposition of "giant SEP" and its computer model for scalp topography. Electroencephalogr Clin Neurophysiol 1990;77:286-294.

5. Shibasaki H, Hallett M. What is the Bereitschaftspotential? Clin Neurophysiol 2006; 117:2341-2356.
6. Grosse P, Cassidy MJ, Brown P. EEG-EMG, MEG-EMG and EMG-EMG frequency analysis: physiological principles and clinical applications. Clin Neurophysiol 2002; 113:1523-1531.

7. Brown P, Farmer SF, Halliday DM, Marsden J, Rosenberg JR. Coherent cortical and muscle discharge in cortical myoclonus. Brain 1999;122:461-472.

8. Shibasaki H, Yamashita Y, Kuroiwa Y. Electroencephalographic studies myoclonus. Brain 1978;101:447-460.

9. Caviness JN, Adler CH, Beach TG, Wetjen KL, Caselli RJ. Small-amplitude cortical myoclonus in Parkinson's disease: physiology and clinical observations. Mov Disord 2002;17:657-662.

10. Sinha S, Satishchandra P, Gayathri N, Yasha TC, Shankar SK. Progressive myoclonic epilepsy: a clinical, electrophysiological and pathological study from South India. J Neurol Sci 2007;252:16-23.

11. Binelli S, Agazzi P, Canafoglia L, et al. Myoclonus in Creutzfeldt-Jakob disease: polygraphic and video-electroencephalography assessment of 109 patients. Mov Disord 2010;25:2818-2827.

12. Zutt R, Elting JW, van der Hoeven JH, Lange F, Tijssen MA. Myoclonus subtypes in tertiary referral center: cortical myoclonus and functional jerks are common. Clin Neurophysiol 2017;128:253-259.

13. Fermanian J. Measuring agreement between 2 observers: a quantitative case [in French]. Rev Epidemiol Sante Publique 1984;32:408-413.

14. Landis JR, Koch GG. The measurement of observer agreement for categorical data. Biometrics 1977;33:159-174.

15. Louis ED, Ottman R, Hauser WA. How common is the most common adult movement disorder? Estimates of the prevalence of essential tremor throughout the world. Mov Disord 1998;13:5-10.

16. Caviness JN, Alving LI, Maraganore DM, Black RA, McDonnell SK, Rocca WA. The incidence and prevalence of myoclonus in Olmsted County, Minnesota. Mayo Clin Proc 1999; 74:565-569.

17. van der Stouwe AM, Elting JW, van der Hoeven JH, et al. How typical are "typical" tremor characteristics? Sensitivity and specificity of five tremor phenomena. Parkinsonism Relat Disord 2016;30:23-28.

18. Rossi Sebastiano D, Soliveri P, Panzica F, et al. Cortical myoclonus in childhood and juvenile onset Huntington's disease. Parkinsonism Relat Disord 2012;18:794-797.

19. Tassinari CA, Rubboli G, Shibasaki H. Neurophysiology of positive and negative myoclonus. Electroencephalogr Clin Neurophysiol 1998;107:181-195.

20. Shibasaki H, Hallett M. Electrophysiological studies of myoclonus. Muscle Nerve 2005;31:157-174.

21. Grosse P, Guerrini R, Parmeggiani L, Bonanni P, Pogosyan A, Brown P. Abnormal corticomuscular and intermuscular coupling in high-frequency rhythmic myoclonus. Brain 2003; 126:326-342.

22. Shibasaki H, Yamashita Y, Neshige R, Tobimatsu S, Fukui R. Pathogenesis of giant somatosensory evoked potentials in progressive myoclonic epilepsy. Brain 1985;108: $225-240$.

23. Obeso JA, Rothwell JC, Marsden CD. Somatosensory evoked potentials in myoclonus. Adv Neurol 1986;43:373-384.

24. Bakker MJ, van Dijk JG, van den Maagdenberg AM, Tijssen MA. Startle syndromes. Lancet Neurol 2006;5:513-524.

25. Brown P, Rothwell JC, Thompson PD, Britton TC, Day BL, Marsden CD. The hyperekplexias and their relationship to the normal startle reflex. Brain 1991;114: 1903-1928.

26. Marelli C, Canafoglia L, Zibordi F, et al. A neurophysiological study of myoclonus in patients with DYT11 myoclonus-dystonia syndrome. Mov Disord 2008;23: 2041-2048.

27. Brown P, Thompson PD, Rothwell JC, Day BL, Marsden CD. Axial myoclonus of propriospinal origin. Brain 1991;114:197-214.

28. Brown P, Rothwell JC, Thompson PD, Marsden CD. Propriospinal myoclonus: evidence for spinal "pattern" generators in humans. Mov Disord 1994;9:571-576.

29. Zutt R, Elting JW, Tijssen MAJ. Myoclonus. In: Wolters Baumann EC, editors. Parkinson Disease and Other Movement Disorders. 1st ed. Amsterdam: VU University Press; 2014:513-533.

30. Hinson VK, Haren WB. Psychogenic movement disorders. Lancet Neurol 2006;5: 695-700.

31. van der Salm SM, Tijssen MA, Koelman JH, van Rootselaar AF. The bereitschaftspotential in jerky movement disorders. J Neurol Neurosurg Psychiatry 2012;83:1162-1167. 


\section{Electrophysiologic testing aids diagnosis and subtyping of myoclonus}

Rodi Zutt, MD, Jan W. Elting, MD, PhD, Jonathan C. van Zijl, MD, J. Han van der Hoeven, MD, PhD, Christiaan M. Roosendaal, MD, Jeannette M. Gelauff, MD, Kathryn J. Peall, MD, PhD, and Marina A.J. Tijssen, MD, PhD

Cite as: Neurology ${ }^{\circledR}$ 2018;90:e647-e657. doi:10.1212/WNL.0000000000004996

\section{Correspondence}

Dr. Tijssen

m.a.j.de.koningtijssen@

umcg.nl

\section{Study question}

Can electrophysiologic testing contribute to the diagnosis and anatomical classification of myoclonus?

\section{Summary answer}

Electrophysiologic testing can aid the diagnosis and anatomical classification of myoclonus.

\section{What is known and what this paper adds}

Electrophysiologic testing is frequently used in the differential diagnosis and anatomical classification of myoclonus, but its sensitivity and specificity are poorly understood. This study evaluates the diagnostic utility of electrophysiologic testing in a large cohort of patients.

\section{Participants and setting}

The study prospectively recruited 72 patients who were initially diagnosed with myoclonus between July 2014 and June 2016 and referred to the University Medical Center Groningen. The initial diagnosis subtypes included cortical myoclonus (25), subcortical myoclonus (7), spinal myoclonus (2), functional myoclonic jerks (15), and unclassifiable myoclonus (23). The median Unified Myoclonus Rating Scale score was 27 (range 5-85), and the median Global Clinical Impression-Severity score was 4 (range 2-7).

\section{Design, size, and duration}

Initial clinical diagnoses were provided by the participants' primary neurologists and based on standardized, systemic evaluations that included videotaped clinical examinations. The electrophysiologic testing started with polymyography. Those meeting the electrophysiologic criteria for myoclonus underwent further testing that could include EEG-EMG or coherence analysis. An experienced neurophysiologist provided diagnoses based on the electrophysiologic test results. For a gold standard comparison, a movement disorder specialist provided diagnoses based on the clinical details, videotaped clinical examinations, and electrophysiologic test results. All reviewers were blinded to initial diagnoses.

\section{Main results and the role of chance}

Of the 66 patients who underwent complete electrophysiologic testing, a neurophysiologist diagnosed myoclonus in 60 (91\%).

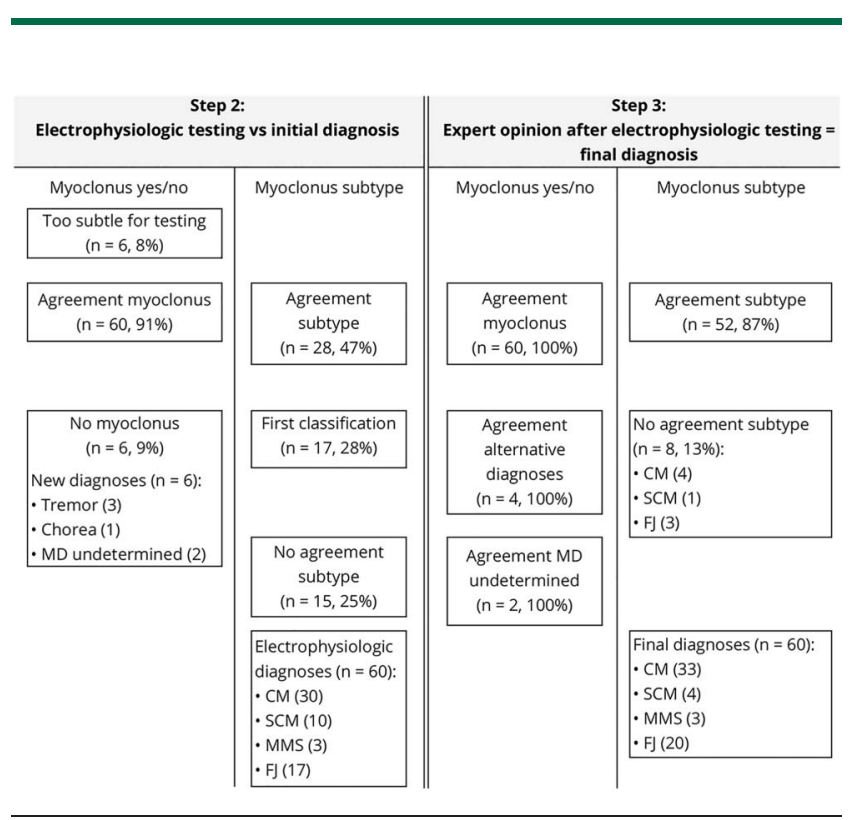

Subtype agreement with the initial diagnosis was achieved for 28 (47\%) cases. In distinguishing myoclonus cases from nonmyoclonus cases, the movement disorder specialist concurred with the neurophysiologist for all $66(100 \%)$ cases. For the 60 cases with a final diagnosis of myoclonus, the movement disorder specialist concurred with the neurophysiologist on myoclonus subtype in $52(87 \%)$ patients.

\section{Bias, confounding, and other reasons for caution}

The study lacked a definitive diagnostic test or marker.

\section{Generalizability to other populations}

Complex cases are probably overrepresented in the study cohort, and this may limit generalizability to patients encountered in routine clinical practice.

\section{Study funding/potential competing interests}

The study received no funding. Some authors report receiving funding from the University of Groningen, national research councils, medical research foundations, and various healthcare companies. Go to Neurology.org/ $\mathrm{N}$ for full disclosures. 


\section{Neurology}

\section{Electrophysiologic testing aids diagnosis and subtyping of myoclonus}

Rodi Zutt, Jan W. Elting, Jonathan C. van Zijl, et al.

Neurology 2018;90;e647-e657 Published Online before print January 19, 2018

DOI 10.1212/WNL.0000000000004996

\section{This information is current as of January 19, 2018}

\section{Updated Information \&} Services

\section{References}

Subspecialty Collections

Permissions \& Licensing

\section{Reprints}

including high resolution figures, can be found at: http://n.neurology.org/content/90/8/e647.full

This article cites 30 articles, 1 of which you can access for free at: http://n.neurology.org/content/90/8/e647.full\#ref-list-1

This article, along with others on similar topics, appears in the following collection(s): EEG; see Epilepsy/Seizures

http://n.neurology.org/cgi/collection/eeg_see_epilepsy-seizures EMG

http://n.neurology.org/cgi/collection/emg

Myoclonus

http://n.neurology.org/cgi/collection/myoclonus

Information about reproducing this article in parts (figures,tables) or in its entirety can be found online at:

http://www.neurology.org/about/about_the_journal\#permissions

Information about ordering reprints can be found online:

http://n.neurology.org/subscribers/advertise

Neurology ${ }^{\circledR}$ is the official journal of the American Academy of Neurology. Published continuously since 1951, it is now a weekly with 48 issues per year. Copyright @ 2018 The Author(s). Published by Wolters Kluwer Health, Inc. on behalf of the American Academy of Neurology.. All rights reserved. Print ISSN: 0028-3878. Online ISSN: 1526-632X.

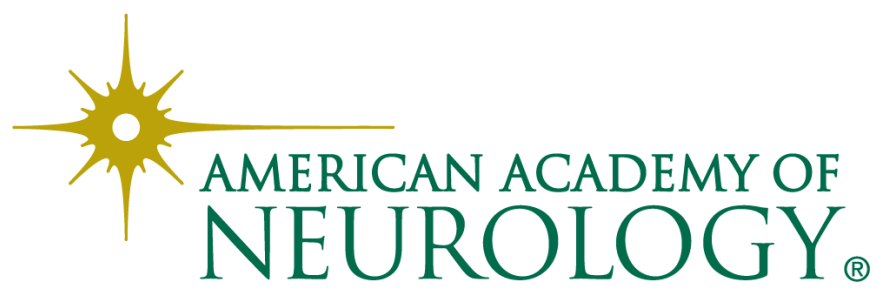

